\title{
Hyperosmotic arabinose solutions open the tight junctions between brain capillary endothelial cells in tissue culture
}

\author{
KATERINA DOROVINI-ZIS ${ }^{1}$, PHILLIP D. BOWMAN ${ }^{2}$, A. LORRIS BETZ 3 and GARY W. GOLDSTEIN 3 \\ Departments of ${ }^{1}$ Pathology (Neuropathology), ${ }^{2}$ Pediatrics and ${ }^{3}$ Neurology, \\ University of Michigan, Ann Arbor, MI 48109 (U.S.A.)
}

(Accepted February 14th, 1984)

Key words: brain capillary endothelium — tight junctions — arabinose — horseradish peroxidase

\begin{abstract}
Tight junctions between bovine brain capillary endothelial cells in primary cell culture are impermeable to horseradish peroxidase (HRP) after $5 \mathrm{~min}$ of incubation. However, following 1-5 min of exposure to $1.6 \mathrm{M}$ arabinose, HRP penetrates the extracellular space between successive tight junctions. Endothelial cells in control cultures contain a small number of cytoplasmic pits and vesicles containing HRP which do not increase in number after hyperosmotic treatment.
\end{abstract}

Endothelial cells of brain capillaries are joined together by continuous tight junctions and contain few pinocytotic vesicles. These features result in the formation of a blood-brain barrier (BBB) which restricts the movement of proteins from blood to brain. This barrier, however, can be opened by perfusion of the cerebral vasculature with hyperosmotic me$\mathrm{dia}^{4} .5,9,11,12$. Whether this breakdown of the barrier is the result of altered junctional permeability $4,5,9,11$ or an increase in the rate of trans-endothelial vesicular transport 7.12 has not been established with certainty using in vivo preparations.

Our laboratory has recently reported methods ${ }^{2,3}$ for the purification and growth of brain capillary endothelial cells in tissue culture. These cells are bound together by numerous tight junctions and, therefore, should provide a convenient in vitro model for studies of altered BBB permeability. In the present study we used the protein tracer, horseradish peroxidase (HRP), to investigate the permeability of monolayers of cultured brain capillary endothelial cells under control conditions and after exposure to hyperosmotic solutions of arabinose.

Primary cultures of capillary endothelium from bovine brain were derived as previously described ${ }^{2}$.
The cells were grown in $\alpha$-MEM medium (Gibco) containing $10 \%$ plasma-derived porcine serum, $100 \mu \mathrm{g} / \mathrm{ml}$ penicillin, $100 \mu \mathrm{g} / \mathrm{ml}$ streptomycin, and $2.5 \mu \mathrm{g} / \mathrm{ml}$ Fungizone. The monolayers reached confluence by 7 days and were routinely used for this study between 14 and 21 days in culture.

The cultured cells were washed 3 times over 15 min with serum-free medium and then incubated at room temperature in media containing $1 \mathrm{mg} / \mathrm{ml}$ of HRP (Type VI, Sigma) and either 0 (control) or $1.6 \mathrm{M}$ arabinose. After various periods of time, the HRP-containing solutions were removed and the cells were fixed for $1 \mathrm{~h}$ at room temperature in a solution of $2.5 \%$ glutaraldehyde and $2 \%$ paraformaldehyde in $0.1 \mathrm{M}$ sodium cacodylate buffer ( $\mathrm{pH} 7.35$ ). The fixed cells were then washed in cacodylate buffer and incubated for $1 \mathrm{~h}$ at $4{ }^{\circ} \mathrm{C}$ in $3,3^{\prime}$-diamino-benzidine $(0.5 \mathrm{mg} / \mathrm{ml})$ to permit histochemical identification of HRP. The cells were post-fixed in $1 \%$ buffered solution of osmium tetroxide, stained en bloc with uranyl magnesium acetate, dehydrated and embedded in Epon-Araldite. Selected areas of the monolayers were cut out and re-embedded into molds to obtain transverse sections of the endothelial cells. Thin sections were examined in a Philips EM 400

Correspondence: K. Dorovini-Zis, Department of Pathology, Division of Neuropathology, 1335 E. Catherine St., University of Michigan, Box 045, Ann Arbor, MI 48109, U.S.A. 

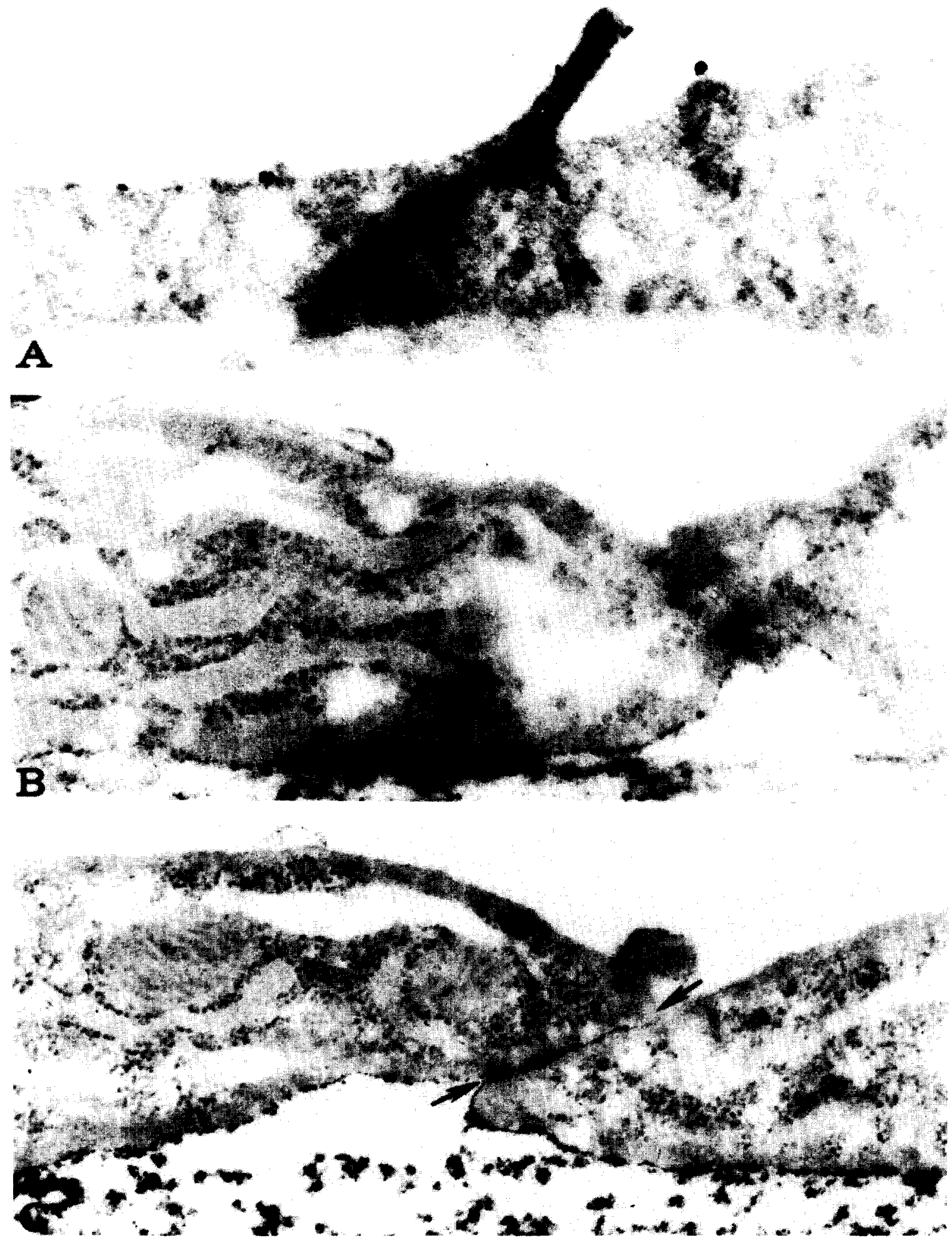

Fig. 1. A: control. Five minutes after exposure to HRP, the cleft between two adjacent endothelial cells contains no tracer. The HRP forms small discrete patches on the surface of the cells but does not penetrate beyond the first tight junction (arrow). The basal surface is free of HRP. $\times 82,500$. B: two minute exposure to 1.6 M arabinose. The extracellular spaces between successive tight junctions (arrow heads) contain deposits of HRP. The basal surfaces are labelled with small amounts of the tracer. $\times 66,000$. C: Five minute exposure to 1.6 M arabinose. HRP penetrates throughout the entire length of an inter-endothelial cleft (between arrows) and forms dense deposits on the basal surface of the cells. $\times 39,000$. 
TABLE I

Inter-endothelial clefts and cytoplasmic vesicles containing HRP in experimental and control cultures

\begin{tabular}{llll}
\hline & $\begin{array}{l}\text { Number of inter-endothelial } \\
\text { clefts counted }\end{array}$ & Number open to HRP & $\begin{array}{l}\text { Labelled cytoplasmic vesicles } \\
\text { per 100 cells }\end{array}$ \\
\hline Control (5 min) & 120 & 0 & 45 \\
$1.6 \mathrm{M}$ arabinose $(1-5 \mathrm{~min})$ & 245 & 115 & 34 \\
\hline
\end{tabular}

electron microscope without heavy metal staining.

The endothelial cells appeared elongated and flattened with long overlapping processes. Finger-like cytoplasmic folds usually identified the site of cell apposition. Cell contacts varied in length and complexity as did the number of tight junctions along these contacts. At least 2 or 3 inter-endothelial tight junctions were present between adjoining cells. A discontinuous layer of basement membrane-like material was often found under their basal surface.

In control cultures, no tracer had penetrated beyond the first tight junction after 5 min exposure to HRP (Fig. 1A). In contrast, the cultures exposed to
1.6 $\mathrm{M}$ arabinose contained HRP within many interendothelial clefts and the tracer frequently filled the entire length of the cell contact. This penetration of HRP occurred as early as $1-2$ min after exposure to arabinose (Fig. 1B) and by $5 \mathrm{~min}$, a dense accumulation of HRP was noted underlying the basal plasma membrane of these cells (Fig. 1C). To quantitate these changes, 120 inter-endothelial clefts were examined in the control and 245 in the arabinose-treated monolayers. As shown in Table I, HRP did not penetrate any of the junctions in control cells while $47.5 \%$ of the clefts in the arabinose-treated cultures contained HRP.
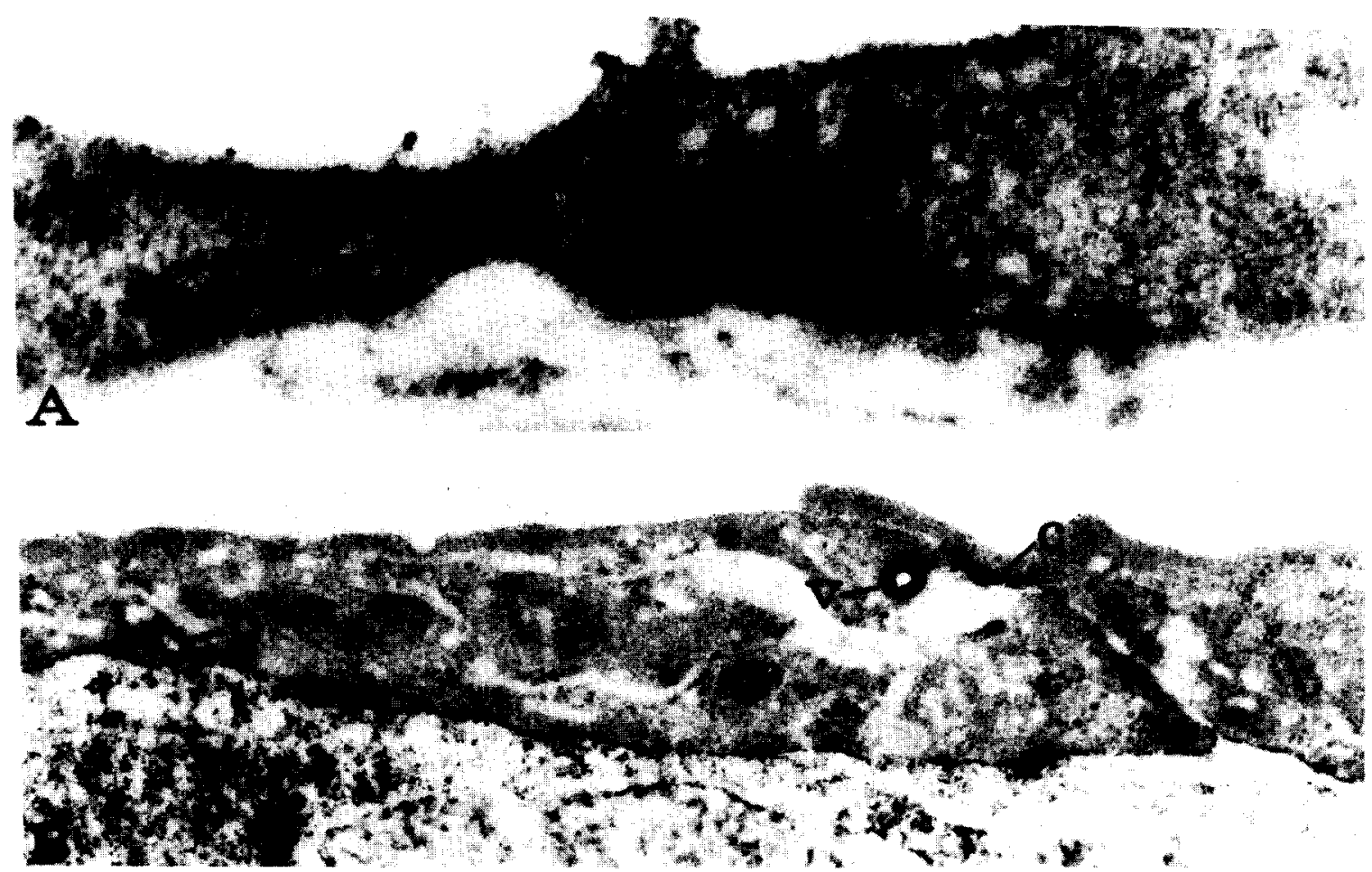

Fig. 2. A: control. Five minutes after exposure to HRP, cytoplasmic vesicle (v) contains HRP. No HRP in adjacení inter-endothelial cleft (arrow heads) or basal surfaces. $\times 64,500$. B: three minute exposure to $1.6 \mathrm{M}$ arabinose. Cytoplasmic vesicle (v), pit (p) and endothelial cleft (c) partly filled with HRP. Dense deposits of HRP on the undersurface of the cells. $\times 42,500$. 
It has been proposed that increased vesicular transport is a mechanism by which BBB permeability is increased in certain conditions $1,6-8,10,12,13$. Therefore, we examined our tissue sections for evidence of vesicular transport. Although occasional cytoplasmic vesicles and pits were seen labelled with $H R P$ in the control cells (Fig. 2A), their number did not increase following exposure to hyperosmotic arabinose (Fig. 2B, Table I). Furthermore, the few vesicles seen, never formed chains or channels that traversed the entire width of the endothelial cell.

In summary, brain capillary endothelial cells in culture form a monolayer which does not permit trans-endothelial passage of HRP. However, following exposure to $1.6 \mathrm{M}$ arabinose, inter-endothelial junctions become permeable to HRP. We found no evidence for trans-endothelial vesicular transport in

1 Beggs, J. L. and Waggener, J. D., Transendothelial vesicular transport of protein following compression injury to the spinal cord, Lab. Invest., 34 (1976) 428-439.

2 Bowman, P. D., Betz, A. L., Ar., D., Wolinsky, J. S., Penney, J. B., Shivers, R. R. and Goldstein, G. W., Primary culture of capillary endothelium from rat brain, In Vitro, 17 (1981) 353-362.

3 Bowman, P. D., Ennis, S., R., Rarey, K. E., Betz, A. L. and Goldstein, G. W., Brain microvessel endothelial cells in tissue culture: a model for study of blood-brain barrier permeability, Ann. Neurol, 14 (1983) 396-402.

4 Brightman, M. W., Hori, M., Rapoport, S. I., Reese, T. S. and Westergaard, E., Osmotic opening of tight junctions in cerebral endothelium, J. comp. Neurol., 152 (1973) $317-326$.

5 Dorovini-Zis, K., Sato, M., Goping, G., Rapoport, S. I. and Brightman, M. W., Ionic lanthanum passage across cerebral endothelium exposed to hyperosmotic arabinose, Acta neuropath. (Berl.), 60 (1983) 49-60.

6 Horton, J. C. and Hedley-Whyte, E. T., Protein movement across the blood-brain barrier in hypervolemia, Brain Research, 169 (1979) 610-614.

7 Houthoff, H. J., Go, K. G. and Gerrits, P. O., The mechanisms of blood-brain impairment by hyperosmolar perfu- either control or treated cell cultures. These results support the in vivo studies showing increased junctional permeability after infusion of hyperosmotic solutions ${ }^{4,5}$. Using our in vitro system it should now be possible to study the mechanisms involved in the formation and disruption of the tight junctions in brain capillaries.

This study was supported by a Teacher Investigator Award (1K07NS00708) from the National Institutes of Health and by a Faculty Research Grant from the Rackham School of Graduate Studies (K.D.-Z.) and by the National Foundation-March of Dimes and Grants HL-25492 and ES-02380 from the National Institutes of Health. A.L.B. is the recipient of an Established Investigatorship from the American Heart Association.

sion, Acta neuropath. (Berl.), 56 (1982) 99-112.

8 Nag, S., Robertson, D. M. and Dinsdale, H. B., Quantitative estimate of pinocytosis in experimental acute hypertension, Acta neuropath. (Berl.), 46 (1979) 107-116.

9 Nagy, Z., Pappius, H. M., Mathieson, G. and Hüttner, I., Opening of tight junctions in cerebral endothelium. I. Effect of hyperosmolar mannitol infused through the internal carotid artery, J. comp. Neurol., 185 (1979) 569-578.

10 Petito, C. K., Schaefer, J. A. and Plum, F., Ultrastructural characteristics of the brain and blood-brain barrier in experimental seizures, Brain Research, 127 (1977) 251-267.

11 Rapoport, S. I., Hori, M. and Klatzo, I., Testing of a hypothesis for osmotic opening of the blood-brain barrier, Amer. J. Physiol., 223 (1972) 323-331.

12 Shivers, R. R., The effect of hyperglycemia on brain capillary permeability in the lizard, Anolis carolinensis. A freeze-fracture analysis of blood-brain barrier pathology, Brain Research, 170 (1979) 509-522.

13 Westergaard, E., Ultrastructural permeability properties of cerebral microvasculature under normal and experimental conditions after application of tracers. In J. Cervos-Navarro and R. Ferszt (Eds.), Advances in Neurology, Vol. 28, Raven Press, New York, 1980, pp. 55-74. 